UCRL-JC-123265

PREPRINT

$$
\text { CONF- } 960772--5
$$

Experimental and Modeling Investigation of Aromatic and Polycyclic Aromatic Hydrocarbon Formation in a Premixed Ethylene Flame

\author{
M. J. Castaldi \\ N. M. Marinov \\ C. F. Melius \\ J. Huang \\ S. M. Senkan \\ W. J. Pitz \\ C. K. Westbrook
}

RECEIVED

MAR 181996

OSTI

This paper was prepared for submittal to the 26th International Symposium on Combustion

Naples, Italy

July 28-August 2, 1996

February 1996

This is a preprint of a paper intended for publication in a journal or proceedings. Since changes may be made before publication, this preprint is made available with the understanding that it will not be cited or reproduced without the permission of the author.

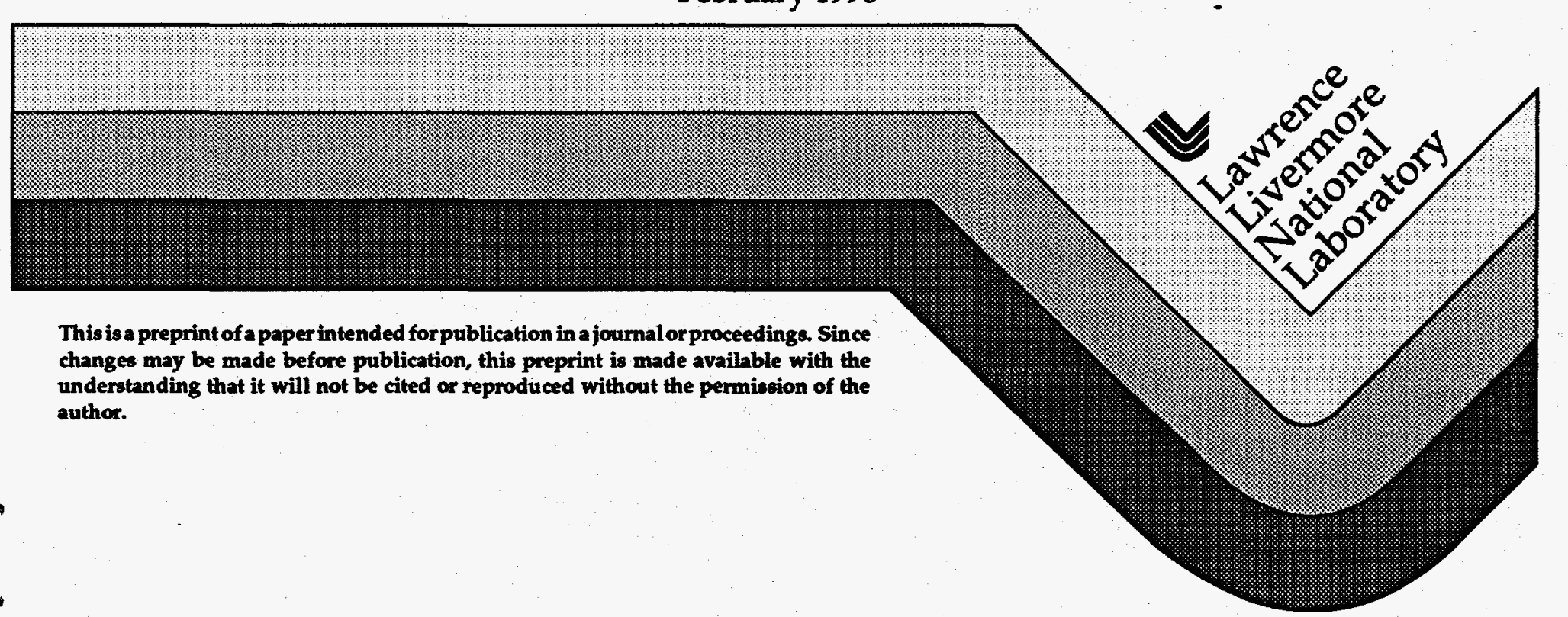




\section{DISCLAIMER}

This document was prepared as an account of work sponsored by an agency of the United States Government. Neither the United States Government nor the University of California nor any of their employees, makes any warranty, express or implied, or assumes any legal liability or responsibility for the accuracy, completeness, or usefulness of any information, apparatus, product, or process disclosed, or represents that its use would not infringe privately owned rights. Reference herein to any specific commercial products, process, or service by trade name, trademark, manufacturer, or otherwise, does not necessarily constitute or imply its endorsement, reconmendation, or favoring by the United States Government or the University of Califomia. The views and opinions of authors expressed herein do not necessarily state or reflect those of the United States Government or the University of California, and shall not be used for advertising or product endorsement purposes. 


\section{DISCLATMER}

Portions of this document may be illegible in electronic image products. Images are produced from the best available original document. 


\title{
Experimental and Modeling Investigation of Aromatic and Polycyclic Aromatic Hydrocarbon Formation in a Premixed Ethylene Flame
}

\author{
Marco J. Castaldi§ , Nick M. Marinov†, Carl F. Melius $\ddagger$, Jaimei Huang§, \\ Selim M. Senkan§, William J. Pitz $\dagger_{\text {, and Charles K. Westbrook } †}$ \\ §University of California at Los Angeles, Los Angeles, Ca. 90024 \\ tLawrence Livermore National Laboratory, Livermore, Ca. 94551 \\ ¥Sandia National Laboratories, Livermore, Ca. 94551
}

\author{
Correspondence should be addressed to: \\ Nick Marinov \\ Lawrence Livermore National Laboratory \\ P.O. Box 808 \\ Livermore, California 94551 \\ Phone: (510) 424-5463 \\ Fax: (510) 422-2851 \\ Internet: marinov@llnl.gov
}

Preference: Oral

Colloquium Topic Area:

General Reaction Kinetics

Soot and PAH

Word count:

Text

3800 words

References $\quad 300$ words

Figures

Total

1800 words

5900 words

(Introduction through Acknowledgment, counted with Microsoft Word 5.0)

Microsoft Word 5.0

(9 figures@200words) 


\title{
Experimental and Modeling Investigation of Aromatic and Polycyclic Aromatic Hydrocarbon Formation in a Premixed Ethylene Flame
}

\author{
Marco J. Castaldi§ , Nick M. Marinov†, Carl F. Melius $\ddagger$, Jiamei Huang§, \\ Selim M. Senkan§, William J. Pitz $†$, and Charles K. Westbrook $†$ \\ SUniversity of California at Los Angeles, Los Angeles, Ca. 90024 \\ tLawrence Livermore National Laboratories, Livermore, Ca. 94551 \\ †Sandia National Laboratories, Livermore, Ca. 94551
}

\begin{abstract}
Experimental and detailed chemical kinetic modeling has been performed to investigate aromatic and polyaromatic hydrocarbon formation pathways in a rich, sooting, ethyleneoxygen-argon premixed flame. An atmospheric pressure, laminar flat flame operated at an equivalence ratio of 2.5 was used to acquire experimental data for model validation. Gas composition analysis was conducted by an on-line gas chromatograph / mass spectrometer (GC/MS) technique. Measurements were made in the flame and post-flame zone for a number of low molecular weight species, aliphatics, aromatics and polycyclic aromatic hydrocarbons (PAHs) ranging from two to five-aromatic fused rings.

The modeling results show the key reaction sequences leading to aromatic and polycyclic aromatic hydrocarbon growth involve the combination of resonantly stabilized radicals. In particular, propargyl and 1-methylallenyl combination reactions lead to benzene and methyl substituted benzene formation, while polycyclic aromatics are formed from cyclopentadienyl radicals and fused rings that have a shared $C_{5}$ side structure. Naphthalene production through the reaction step of cyclopentadienyl self-combination and phenanthrene formation from indenyl and cyclopentadienyl combination were shown to be important in the flame modeling study. The removal of phenyl by $\mathrm{O}_{2}$ leading to cyclopentadienyl formation is expected to play a pivotal role in the PAH or soot precursor growth process under fuel-rich oxidation conditions.
\end{abstract}




\section{Introduction}

The U.S. Clean Air Act Amendments of 1990 has stipulated the emission regulation of 189 compounds called air toxics. These air toxics include formaldehyde, butadiene, aromatic and some polycyclic aromatic hydrocarbons (PAHs). The PAH's are of particular concern because several isomers are potent mutagens and carcinogens. Polycyclic aromatics are formed in fuel-rich regions of practical combustion devices such as process heaters and boilers. They may be emitted as pollutants, depending on burner operating conditions and design. Thus, it is important to identify the chemical and fluid dynamical mechanisms that lead to PAH formation and emission in industrial burners. However, it is difficult to study the chemistry of PAH formation in the highly-turbulent environment of an industrial burner. In this study, PAH formation is investigated in a well-controlled, and wellcharacterized one-dimensional laboratory burner.

Previous modeling studies on fuel-rich ethylene combustion [1 - 4] have primarily focused on aliphatic chemistry for the purpose of developing a detailed understanding of the pathways leading to higher order stable and radical hydrocarbons that serve as the underlying foundation to aromatic and polycyclic aromatic growth. We are aware of only one detailed chemical kinetic modeling study to date that has examined the aliphatic chemistry implications in aromatic formation for an ethylene flame [1]. Experimental studies on polycyclic aromatic growth in flames [5] have been limited because the presence of soot can make measurements difficult, and modeling studies [6] have been limited as chemistry and thermodynamics are not well understood for flame modeling of benzoid molecules and soot.

In this paper, a previously developed detailed chemical kinetic model for rich premixed methane and ethane flames [7] was used to interpret the experimental results of a rich, sooting, premixed ethylene-oxygen-argon flame. In addition to reaction steps proposed previously for the formation of aromatics and PAHs [8,9], several novel reactions are advocated in the presented work. These new steps involve the combination 
reactions of resonantly stabilized 1-methylallenyl and propargyl radicals which lead to aromatic formation without having to form benzene first and the combination of cyclopentadienyl radicals leading to 2 and 3-aromatic fused ring (PAHs). As shown later, predicted stable species concentrations based on these new steps compared favorably to measured concentrations in a rich, sooting, premixed laminar flame of ethylene. In the following sections, the experimental apparatus is described, the chemical kinetic model is discussed, and the experimental and modeling results are compared.

\section{Experimental}

The experimental system has been described in a previous publication [7], and thus, only a brief summary will be given here. The atmospheric-pressure, premixed, laminar, flat-flame of $21.30 \% \mathrm{C}_{2} \mathrm{H}_{4} / 20.90 \% \mathrm{O}_{2} / 57.8 \% \mathrm{Ar}(\phi=2.5,7.56 \mathrm{liter} / \mathrm{min}$ gas flow rate) was stabilized over a cooled $50 \mathrm{~mm}$ diameter porous bronze burner. The flame was protected from the ambient environment by use of a concentric shield gas stream of argon. Gas sampling was performed using two quartz microprobes operated at 50 Torr internal pressure. The two probes differed in orifice diameter so as to sample gases in the main reaction zone and in the sooty region of the post-flame zone. This combined sampling approach coupled with the on-line gas chromatograph/mass spectrometer (GC/MS) gas analysis technique allowed for spatially resolved micro-structure measurements of the ethylene flame.

The gas sampling system, which include the probe, silica-lined tubing, and GC valves were maintained above $300^{\circ} \mathrm{C}$ and at sub-ambient pressures to minimize the condensation and/or adsorption of PAHs on surfaces. The sampling system was also checked for possible catalytic activity at $300^{\circ} \mathrm{C}$ by passing unburned gas mixtures; none was observed.

Identification of species were accomplished by matching both the gas chromatographic retention times to pure components and mass spectral fragmentation 
patterns to standard MS libraries. The estimated accuracy for the major species is $\pm 15 \%$ and $\pm 20 \%$ for the remaining ones. The relative ionization cross section (IC) method was used to quantify those species whose calibration standards were not available [10]. Those species whose concentrations were determined by the relative ionization cross section method were $\mathrm{C}_{3} \mathrm{H}_{4}$ (allene and propyne), $\mathrm{C}_{4} \mathrm{H}_{2}$ (diacetylene), $\mathrm{C}_{4} \mathrm{H}_{4}$ (vinylacetylene), $\mathrm{C}_{4} \mathrm{H}_{6}$ (1,2 or 1,3-butadiene, and 1 or 2-butyne), $\mathrm{C}_{4} \mathrm{H}_{8}$ (1 or 2-butene), $\mathrm{c}_{-} \mathrm{C}_{5} \mathrm{H}_{6}$ (cyclopentadiene), $\mathrm{C}_{6} \mathrm{H}_{5} \mathrm{CH}_{3}$ (toluene), $\mathrm{C}_{6} \mathrm{H}_{5} \mathrm{C}_{2} \mathrm{H}_{5}$ (ethylbenzene), $\mathrm{C}_{6} \mathrm{H}_{5} \mathrm{C}_{2} \mathrm{H}_{3}$ (styrene), $\mathrm{C}_{6} \mathrm{H}_{5} \mathrm{C}_{2} \mathrm{H}$ (phenylacetylene), $\mathrm{CH}_{3} \mathrm{C}_{6} \mathrm{H}_{4} \mathrm{CH}_{3}$ (o-xylene), $\mathrm{C}_{9} \mathrm{H}_{7}$ (indene), $\mathrm{C}_{11} \mathrm{H}_{10}$ (methyl napthalene), $\mathrm{C}_{12} \mathrm{H}_{8}$ (acenapthalene and biphenylene), $\mathrm{C}_{12} \mathrm{H}_{10}$ (biphenyl), and $\mathrm{C}_{18} \mathrm{H}_{10}$ (cyclopenta[cd]pyrene and benzo[ghi]fluoranthene). The uncertainty attributed to these species measurements is at least a factor of two.

Temperature profiles were measured by using $0.075 \mathrm{~mm} \mathrm{Pt} \mathrm{Pt} / 13 \% \mathrm{Rh}$ thermocouple wires with a bead diameter of ca. $0.15 \mathrm{~mm}$ and were performed immediately after the concentration measurements. The thermocouple bead was freshly coated by silica and vitrified before each experiment to minimize catalysis. The thermocouple was kept in the flame for as little time as possible to prevent excessive soot buildup. Any accumulated soot was burned off by moving the thermocouple to the non-sooting region of the flame. The flame temperature measurements were corrected for radiation losses. We have assumed an emissivity value of 0.90 . This results in a maximum correction in temperature of ca. $80 \mathrm{~K}$ at $2.0 \mathrm{~mm}$ above the burner surface.

\section{Computational Model and Mechanism}

The computational model used in this study is the Sandia laminar one-dimensional premixed flame (PREMIX) code [11]. Thermochemical information was primarily obtained from the Chemkin thermodynamic database [12], Burcat and McBride [13] and, Stein and co-workers $[14,15]$. Unavailable thermodynamics for some species were estimated by group additivity and difference methods [16]. Thermochemical data obtained from sources 
other than the Chemkin thermodynamic database is presented elsewhere [7]. Lastly, the transport parameters were obtained from the Chemkin transport data base [17] and by the method described in Wang and Frenklach [18].

The compiled chemical kinetic mechanism was primarily framed around the MillerMelius benzene formation submechanism [9] , Tsang's propane [19] and propene [20] chemical kinetic reviews, Pitz-Westbrook n-butane submechanism [21], and the EmdeeBrezinsky-Glassman toluene and benzene oxidation submechanisms [22]. The mechanism was extended to allow prediction of methyl-substituted aromatics, and for two to five fused ring structures. The detailed chemical model used in this study consists of 664 reactions and 150 species. The full presentation and discussion of the chemical reactions and kinetic rates used in the detailed mechanism is presented in Marinov et al. [7].

\section{Analysis and Comparison of Modeling Results to the Flame Data}

The modeling results are compared to the experimental results first for the low molecular weight species, and then for the aromatic and PAH species. The key chemical reactions leading to different stable intermediates are identified by reaction flux analysis.

\section{Low Molecular Weight Species in the Ethylene Flame}

The measured and predicted $\mathrm{C}_{2} \mathrm{H}_{4}, \mathrm{O}_{2}, \mathrm{H}_{2}$ and $\mathrm{H}_{2} \mathrm{O}$ concentrations are shown in Fig. 1. For distances greater than $1 \mathrm{~mm}$ above the burner surface, the predicted and measured $\mathrm{C}_{2} \mathrm{H}_{4}$ and $\mathrm{O}_{2}$ concentrations are essentially in agreement. The ethylene was primarily consumed by $\mathrm{C}_{2} \mathrm{H}_{4}+\mathrm{H}_{\leftrightarrow} \leftrightarrow \mathrm{C}_{2} \mathrm{H}_{3}+\mathrm{H}_{2}$ (R1), while the $\mathrm{O}_{2}$ was primarily removed by $\mathrm{HCO}+\mathrm{O}_{2} \leftrightarrow \mathrm{CO}+\mathrm{HO}_{2}(\mathrm{R} 2), \mathrm{C}_{2} \mathrm{H}_{3}+\mathrm{O}_{2} \leftrightarrow \mathrm{CH}_{2} \mathrm{O}+\mathrm{HCO}, \mathrm{C}_{2} \mathrm{H}_{3}+\mathrm{O}_{2} \leftrightarrow \mathrm{CH}_{2} \mathrm{HCO}+\mathrm{O}$ and $\mathrm{HCCO}+\mathrm{O}_{2} \leftrightarrow \mathrm{CO}_{2}+\mathrm{CO}+\mathrm{H}(\mathrm{R} 3)$. The $\mathrm{H}_{2} \mathrm{O}$ profile was underpredicted by a factor of two by the model and this is due to the underprediction of $\mathrm{H}_{2}$ by a factor of 1.7. The $\mathrm{H}_{2} \mathrm{O}$ is formed primarily by $\mathrm{OH}+\mathrm{H}_{2} \leftrightarrow \mathrm{H}_{2} \mathrm{O}+\mathrm{H}$, while the $\mathrm{H}_{2}$ is formed primarily by (R1). 
In Fig. 2, the measured and predicted $\mathrm{CO}, \mathrm{CO}_{2}, \mathrm{CH}_{4}$, and $\mathrm{C}_{2} \mathrm{H}_{2}$ concentrations are shown. The $\mathrm{CO}$ and $\mathrm{CO}_{2}$ were approximately overpredicted by a factor of two, and their formation reactions are $\mathrm{HCO}+\mathrm{M} \leftrightarrow \mathrm{H}+\mathrm{CO}+\mathrm{M}$, (R2) and (R3). The methane concentration was fairly well predicted in the main reaction zone but the model was unable to predict the methane decay further into the post-flame zone. The methane formation reaction sequence was determined to be $\mathrm{C}_{2} \mathrm{H}_{4}+\mathrm{O} \leftrightarrow \mathrm{CH}_{3}+\mathrm{HCO}$ followed by $\mathrm{C}_{2} \mathrm{H}_{4}+\mathrm{CH}_{3} \leftrightarrow \mathrm{C}_{2} \mathrm{H}_{3}+\mathrm{CH}_{4}$. The predicted acetylene levels are a factor of 2 lower than the measurements. Reaction flux analysis indicated the primary acetylene formation pathway was $\mathrm{C}_{2} \mathrm{H}_{3}(+\mathrm{M}) \leftrightarrow \mathrm{C}_{2} \mathrm{H}_{2}+\mathrm{H}(+\mathrm{M})$ with a secondary contribution by the $\mathrm{C}_{2} \mathrm{H}_{3}+\mathrm{O}_{2} \leftrightarrow \mathrm{C}_{2} \mathrm{H}_{2}+\mathrm{HO}_{2}$ metathesis reaction.

In Fig. 3, the measured and predicted ethane $\left(\mathrm{C}_{2} \mathrm{H}_{6}\right)$, allene/propyne (aggregate $\left.\mathrm{C}_{3} \mathrm{H}_{4}\right)$, diacetylene $\left(\mathrm{C}_{4} \mathrm{H}_{2}\right)$, and vinylacetylene $\left(\mathrm{CH}_{2} \mathrm{CHCCH}\right)$ concentrations are shown. The model well predicted the peak ethane concentration location which is due to $\mathrm{CH}_{3}+\mathrm{CH}_{3}(+\mathrm{M}) \leftrightarrow \mathrm{C}_{2} \mathrm{H}_{6}(+\mathrm{M})$. The aggregate $\mathrm{C}_{3} \mathrm{H}_{4}$ concentrations were underpredicted by a factor of ten throughout the flame with respect to the MS/IC measurements which have an uncertainty of more than a factor of 2 . The allene and propyne were produced by the reaction sequence $\mathrm{C}_{2} \mathrm{H}_{3}+\mathrm{CH}_{3}(+\mathrm{M}) \leftrightarrow \mathrm{C}_{3} \mathrm{H}_{6}(+\mathrm{M})$ or $\mathrm{C}_{2} \mathrm{H}_{3}+\mathrm{CH}_{3} \leftrightarrow \mathrm{aC}_{3} \mathrm{H}_{5}$ (allyl) $+\mathrm{H}$, $\mathrm{C}_{3} \mathrm{H}_{6}+\mathrm{H}_{\leftrightarrow} \leftrightarrow \mathrm{aC}_{3} \mathrm{H}_{5}+\mathrm{H}_{2}, \mathrm{aC}_{3} \mathrm{H}_{5}+\mathrm{H} \leftrightarrow \mathrm{aC}_{3} \mathrm{H}_{4}$ (allene) $+\mathrm{H}_{2}$ and $\mathrm{aC}_{3} \mathrm{H}_{4} \leftrightarrow \mathrm{pC}_{3} \mathrm{H}_{4}$ (propyne). Propene was not detected in this flame, however the model predicted a peak $\mathrm{C}_{3} \mathrm{H}_{6}$ concentration of $800 \mathrm{ppm}$ in the main reaction zone. The diacetylene concentrations were underpredicted by ca. one order of magnitude throughout the flame. Effort was made in trying to improve the predicted diacetylene concentration, but we were unable to model the diacetylene measured in this flame without greatly overpredicting the diacetylene measured in the Harris et al. ethylene flame [1]. The diacetylene was predicted to be formed primarily from vinyl acetylene dehydrogenation. The measured $\mathrm{CH}_{2} \mathrm{CHCCH}$ concentrations indicated peak formation occurs around $3.0 \mathrm{~mm}$ above the burner surface then decays in the post-flame zone. The model was unable to predict such a trend and, 
instead, showed a rapid rise in vinylacetylene formation within the main reaction zone followed by slow growth in the post-flame zone. The $\mathrm{C}_{2} \mathrm{H}_{3}+\mathrm{C}_{2} \mathrm{H}_{2} \leftrightarrow \mathrm{CH}_{2} \mathrm{CHCCH}+\mathrm{H}$ reaction was the primary route to $\mathrm{CH}_{2} \mathrm{CHCCH}$ formation.

The measured and predicted aggregate $\mathrm{C}_{4} \mathrm{H}_{6}$ (1,2 and 1,3-butadiene / 1 and 2butyne), aggregate $\mathrm{C}_{4} \mathrm{H}_{8}$ (1-butene/2-butene), and cyclopentadiene (c- $\mathrm{C}_{5} \mathrm{H}_{6}$ ) concentrations along with the radiation corrected temperature profile are shown in Fig. 4. The model well predicted the aggregate $\mathrm{C}_{4} \mathrm{H}_{6}$ concentration in the early stage of the main reaction zone, and exhibited the same $\mathrm{C}_{4} \mathrm{H}_{6}$ decay trend inspite of the factor of ten concentration overprediction in the post-flame zone. Approximately $85 \%$ (main reaction zone) to $95 \%$ (post flame zone) of the $\mathrm{C}_{4} \mathrm{H}_{6}$ consisted of $\mathrm{CH}_{2} \mathrm{CHCHCH}_{2}$, and the remainder due to $\mathrm{CH}_{3} \mathrm{CHCCH}_{2}$ and $\mathrm{CH}_{3} \mathrm{CH}_{2} \mathrm{CCH}$. The main reaction step producing $\mathrm{C}_{4} \mathrm{H}_{6}$ was $\mathrm{C}_{2} \mathrm{H}_{4}+\mathrm{C}_{2} \mathrm{H}_{3} \leftrightarrow \mathrm{CH}_{2} \mathrm{CHCHCH}_{2}+\mathrm{H}$. The measured peak and decay trend of the aggregate $\mathrm{C}_{4} \mathrm{H}_{8}$ concentration was well predicted although the model showed a factor of ten underprediction in the post-flame zone. The aggregate $\mathrm{C}_{4} \mathrm{H}_{8}$ concentration was principally produced by the reaction sequence $\mathrm{aC}_{3} \mathrm{H}_{5}+\mathrm{CH}_{3} \leftrightarrow \mathrm{C}_{4} \mathrm{H}_{8}-1$ (1-butene). The cyclopentadiene $\left(\mathrm{c}-\mathrm{C}_{5} \mathrm{H}_{6}\right)$ concentrations were underpredicted by an order of magnitude in the main reaction zone, but the predictions improved further into the post-flame zone. The model showed a smaller peak concentration followed by a slower decay in the cyclopentadiene concentration than indicated by the measurements. The cyclopentadiene is formed through the oxidation of the aromatic ring by the reaction sequence, $\mathrm{C}_{6} \mathrm{H}_{5}+\mathrm{O}_{2} \leftrightarrow \mathrm{C}_{6} \mathrm{H}_{5} \mathrm{O}+\mathrm{O}, \mathrm{C}_{6} \mathrm{H}_{5} \mathrm{O} \leftrightarrow \mathrm{c}-\mathrm{C}_{5} \mathrm{H}_{5}+\mathrm{CO}$, and $\mathrm{c}-\mathrm{C}_{5} \mathrm{H}_{5}+\mathrm{H} \leftrightarrow \mathrm{c}-\mathrm{C}_{5} \mathrm{H}_{6}$.

Modeling validation was also performed on the Harris et al. [1] $\mathrm{C}_{2} \mathrm{H}_{4} / \mathrm{O}_{2} / \mathrm{Ar}$ data sets for 1.68 and 2.76 equivalence ratio flames at atmosphere pressure. Excellent agreement to within $\pm 20 \%$ was achieved for all major stable species $\left(\mathrm{CO}, \mathrm{CO}_{2}, \mathrm{H}_{2}, \mathrm{H}_{2} \mathrm{O}\right.$, $\mathrm{C}_{2} \mathrm{H}_{4}, \mathrm{CH}_{4}, \mathrm{C}_{2} \mathrm{H}_{6}, \mathrm{C}_{2} \mathrm{H}_{2}, \mathrm{C}_{4} \mathrm{H}_{2}, \mathrm{C}_{4} \mathrm{H}_{4}$ and $\mathrm{C}_{4} \mathrm{H}_{6}$ ) measured. 
Aromatic and Polycyclic Aromatics in the Ethylene Flame

Benzene The self combination of the resonantly stabilized propargyl radical accounts for ca. $92 \%$ of benzene $\left(\mathrm{C}_{6} \mathrm{H}_{6}\right)$ production with the remaining contribution due to the

1-methylallenyl and propargyl combination reaction. The model reproduces the benzene formation trend fairly well but underpredicts its concentration by ca. 50\% as shown in Fig. 5. The propargyl-propargyl reaction produces phenyl $\left(\mathrm{C}_{6} \mathrm{H}_{5}\right)$ and $\mathrm{H}$-atoms, whereupon, the phenyl is converted to benzene by $\mathrm{H}$-atoms in the preheat and flame zones and by $\mathrm{H}_{2}$ in the post-flame zone. The formation of the first aromatic ring occurs by two reaction sequences in this flame study. In the first reaction sequence, vinyl radical adds to ethylene to form a chemically activated $\mathrm{CH}_{2} \mathrm{CH}_{2} \mathrm{CHCH}_{2}$ intermediate which ejects an $\mathrm{H}$-atom to form 1,3-butadiene $\left(\mathrm{CH}_{2} \mathrm{CHCHCH}_{2}\right)$. An $\mathrm{H}$-atom is then abstracted from 1,3-butadiene by $\mathrm{H}$-atoms to form the resonantly stabilized i- $\mathrm{C}_{4} \mathrm{H}_{5}\left(\mathrm{CH}_{2} \mathrm{CHCCH}_{2}\right)$ species. The $\mathrm{i}-\mathrm{C}_{4} \mathrm{H}_{5}$ radical plays an important role in propargyl formation in the ethylene flame because of its ability to form a cumulated double bond (i.e., $\mathrm{C}=\mathrm{C}=\mathrm{C}$ ) during resonance. The $\mathrm{H}$-atom combination with i- $\mathrm{C}_{4} \mathrm{H}_{5}$ makes a chemically activated methylallene $\left(\mathrm{CH}_{3} \mathrm{CHCCH}_{2}\right)$ species that primarily decomposes to methyl and propargyl or ejects an $\mathrm{H}$-atom to form a $\mathrm{C}_{4} \mathrm{H}_{5}$ isomer, 1-methylallenyl $\left(\mathrm{CH}_{3} \mathrm{CCCH}_{2}\right)$, as a secondary product. The propargyl radicals then undergo self combination leading to aromatic formation, with a rate constant of $3.0 \mathrm{E} 12 \mathrm{~cm}^{3} / \mathrm{mol}-\mathrm{sec}$ [7].

The second reaction sequence involves the key $\mathrm{C}_{3}$ hydrocarbon formation step of methyl and vinyl combination to form either propene or allyl and $\mathrm{H}$-atoms as products. The propene or allyl radical are then dehydrogenated by $\mathrm{H}$-atoms to form propargyl. This pathway was determined to be the major propargyl formation route in our earlier methane and ethane flame modeling study. However, the reaction sequences discussed above contributed fairly equal to propargyl formation in this study. These reaction sequences coupled with another important propargyl formation sequence, $\mathrm{C}_{2} \mathrm{H}_{2}+\mathrm{O} \leftrightarrow{ }^{1} \mathrm{CH}_{2}+\mathrm{CO}$ and $\mathrm{C}_{2} \mathrm{H}_{2}+{ }^{1} \mathrm{CH}_{2} \leftrightarrow \mathrm{H}_{2} \mathrm{CCCH}+\mathrm{H}$, have been identified as the important aromatic precursor 
growth reaction sequences in methane, ethane, ethylene and acetylene [9] flames. This later propargyl formation mechanism is of minor importance in the present ethylene flame.

The small contribution (ca. 8\%) of benzene formation from the 1-methylallenyl and propargyl combination reaction occurs through the sequence: $\mathrm{CH}_{3} \mathrm{CCCH}_{2}+\mathrm{H}_{2} \mathrm{CCCH}$ $\leftrightarrow \mathrm{C}_{6} \mathrm{H}_{5} \mathrm{CH}_{2}$ (benzyl)+H followed by $\mathrm{C}_{6} \mathrm{H}_{5} \mathrm{CH}_{2}+\mathrm{H} \leftrightarrow \mathrm{C}_{6} \mathrm{H}_{5} \mathrm{CH}_{3}$ (toluene) then $\mathrm{C}_{6} \mathrm{H}_{5} \mathrm{CH}_{3}+\mathrm{H}_{\leftrightarrow} \leftrightarrow \mathrm{C}_{6} \mathrm{H}_{6}+\mathrm{CH}_{3}$ and $\mathrm{C}_{6} \mathrm{H}_{5} \mathrm{CH}_{2}+\mathrm{HO}_{2} \leftrightarrow \mathrm{C}_{6} \mathrm{H}_{5} \mathrm{CHO}+\mathrm{OH}$ then $\mathrm{C}_{6} \mathrm{H}_{5} \mathrm{CHO}+\mathrm{H}$ $\leftrightarrow \mathrm{C}_{6} \mathrm{H}_{6}+\mathrm{HCO}$.

Toluene The key reaction step leading to toluene formation requires the combination of the resonantly stabilized 1-methylallenyl and propargyl radicals as shown above. These radicals react in an analogous manner as to propargyl self-combination and lead to methyl substituted aromatic formation without having to first form benzene. The rate constant assigned to $\mathrm{CH}_{3} \mathrm{CCCH}_{2}+\mathrm{H}_{2} \mathrm{CCCH} \leftrightarrow \mathrm{C}_{6} \mathrm{H}_{5} \mathrm{CH}_{2}+\mathrm{H}$ was assumed to be the same as $\mathrm{H}_{2} \mathrm{CCCH}+\mathrm{H}_{2} \mathrm{CCCH} \leftrightarrow \mathrm{C}_{6} \mathrm{H}_{5}+\mathrm{H}$. The important 1-methylallenyl formation step requires the $\mathrm{i}-\mathrm{C}_{4} \mathrm{H}_{5}\left(\mathrm{CH}_{2} \mathrm{CHCCH}_{2}\right)$ radical to isomerize by $\mathrm{H}$-atom catalysis as shown by, $\mathrm{CH}_{2} \mathrm{CHCCH}_{2}+\mathrm{H} \leftrightarrow \mathrm{CH}_{3} \mathrm{CCCH}_{2}+\mathrm{H}$. The model correctly predicted the location of the peak toluene concentration, the toluene decay trend deep in the post-flame zone, and the toluene concentration in the post-flame zone to within 50\% as shown in Fig. 5.

Naphthalene Previously [7], we considered five different routes to naphthalene production which included the Frenklach proposed $\mathrm{HACA}$ (H-abstraction- $\mathrm{C}_{2} \mathrm{H}_{2}$ addition) mechanism and its associated kinetic rates [23]. That study's result showed the naphthalene production can be reasonably accounted by resonantly stabilized cyclopentadienyl self-combination and is supported again in this study. The cyclopentadienyl radicals and naphthalene are produced through the reaction sequence,

$$
\mathrm{C}_{6} \mathrm{H}_{5}+\mathrm{O}_{2} \leftrightarrow \mathrm{C}_{6} \mathrm{H}_{5} \mathrm{O}+\mathrm{O}
$$




$$
\begin{aligned}
& \mathrm{C}_{6} \mathrm{H}_{5} \mathrm{O} \leftrightarrow \mathrm{c}-\mathrm{C}_{5} \mathrm{H}_{5}+\mathrm{CO} \\
& c-\mathrm{C}_{5} \mathrm{H}_{5}+\mathrm{c}-\mathrm{C}_{5} \mathrm{H}_{5} \leftrightarrow \mathrm{C}_{10} \mathrm{H}_{8}+\mathrm{H}+\mathrm{H}
\end{aligned}
$$

The key step in the naphthalene production process is phenyl oxidation by $\mathrm{O}_{2}$. This pivotal reaction plays an important role in the PAH growth process for this study. Previous work [24] had indicated that if the $\mathrm{C}_{6} \mathrm{H}_{5}+\mathrm{O}_{2}$ reaction competes effectively with the polymerization process, $\mathrm{C}_{6} \mathrm{H}_{5}+\mathrm{nC}_{2} \mathrm{H}_{2} \leftrightarrow \mathrm{PAHs}$, then $\mathrm{PAH}$ production would be hindered. The results from this flame modeling study show that the removal of phenyl by $\mathrm{O}_{2}$ leading to cyclopentadienyl production will form PAHs which are likely precursors to soot growth [25]. If we were to extend the first two steps in the reaction sequence as shown above to the oxidation of activated 2-fused aromatic rings and higher then the overall reaction step, $\mathrm{C}_{2 n+4} \mathrm{H}_{n+4}+\mathrm{O}_{2} \leftrightarrow \mathrm{C}_{2} \mathrm{n}+3 \mathrm{H}_{n+4}+\mathrm{CO}+\mathrm{O}(\mathrm{n}=1,3,5 \ldots)$, indicates fused-rings containing a shared $\mathrm{C}_{5}$ side structure can readily react with cyclopentadienyl radicals by the same mechanism as cyclopentadienyl self-combination [26] and form larger PAHs. However, self-combination of fused-rings containing a shared $\mathrm{C}_{5}$ side structure to form larger PAHs is not likely to occur because aromaticity in either fused-ring structure would have to be destroyed, which would require overcoming a high energy barrier.

The naphthalene formation trend in the post-flame zone was well reproduced by the model as shown in Fig. 5, but the model could not predict its rapid formation fairly near the burner surface. The predicted naphthalene concentration increases rapidly in the main reaction zone and then slowly levels off in the post-flame zone. This was due to the increased phenyl (hence benzene) production coupled with the remaining $\mathrm{O}_{2}$ available in the main reaction and post-flame zones which allows for rapid production of cyclopentadienyl hence the sudden naphthalene concentration rise. The naphthalene concentration then slowly levels out primarily for two reasons. First, the depletion of $\mathrm{O}_{2}$ in the post-flame zone consequently slows the cyclopentadienyl formation needed for 
napthalene production, and secondly, the naphthalene is consumed by abstraction reactions involving $\mathrm{H}$-atoms.

Phenyl Acetylene The model correctly predicted the phenyl acetylene $\left(\mathrm{C}_{6} \mathrm{H}_{5} \mathrm{C}_{2} \mathrm{H}\right)$ formation trend, but underpredicted its concentration in the main reaction and post-flame zones by a factor of 2.5 . The phenyl acetylene production pathway occurs by ethylene addition to phenyl to form styrene and $\mathrm{H}$-atom followed by styrene dehydrogenation by $\mathrm{H}$ atoms. The $\mathrm{C}_{6} \mathrm{H}_{5}+\mathrm{C}_{2} \mathrm{H}_{2} \leftrightarrow \mathrm{C}_{6} \mathrm{H}_{5} \mathrm{C}_{2} \mathrm{H}+\mathrm{H}$ pathway, which might be expected to produce phenyl acetylene, was favored in the reverse direction and served as the primary phenyl acetylene removal step.

Indene. Phenanthrene. Acenaphthylene, and Pyrene The measured and predicted concentrations of these species are shown in Fig. 6 . The indene was underpredicted by a factor of ten throughout the flame, and its formation pathway occurs by either the reaction step $\mathrm{C}_{6} \mathrm{H}_{5} \mathrm{CH}_{2}+\mathrm{C}_{2} \mathrm{H}_{2} \leftrightarrow$ Indene $+\mathrm{H}$ or by the reaction sequence $\mathrm{C}_{10} \mathrm{H}_{8}+\mathrm{H}_{\leftrightarrow} \leftrightarrow \mathrm{C}_{10} \mathrm{H}_{7}+\mathrm{H}_{2}$, $\mathrm{C}_{10} \mathrm{H}_{7}+\mathrm{O}_{2} \leftrightarrow \mathrm{C}_{10} \mathrm{H}_{7} \mathrm{O}+\mathrm{O}, \mathrm{C}_{10} \mathrm{H}_{7} \mathrm{O} \leftrightarrow$ Indenyl $+\mathrm{CO}$ and Indenyl $+\mathrm{H} \leftrightarrow$ Indene. The phenanthrene formation trend was well predicted and the model predicted its concentration in the post-flame zone to within a factor of two. The phenanthrene formation step was Indenyl $+\mathrm{c}-\mathrm{C}_{5} \mathrm{H}_{5} \leftrightarrow \mathrm{Phenanthrene}+\mathrm{H}+\mathrm{H}$. Acenaphthylene was underpredicted by a factor ten throughout the flame even though its concentration was accurately modeled in our previous work [7] using the reaction step, Indenyl $+\mathrm{H}_{2} \mathrm{CCCH} \leftrightarrow$ Acenaphthylene $+\mathrm{H}+\mathrm{H}$. Pyrene was underpredicted by a factor of twenty through the flame. The model could not reproduce the pyrene measured in this flame with the Phenanthryl- $1+\mathrm{C}_{2} \mathrm{H}_{2} \leftrightarrow$ Pyrene $+\mathrm{H}$ reaction step and its rate constant obtained from [23].

Ethyl Benzene, O-Xylene, Styrene, Anthracene, and 9h-Fluorene The measured and predicted concentrations of these species are shown in Fig. 7. Ethyl benzene was 
underpredicted by a factor ten throughout the flame. The main ethyl-benzene production and destruction routes for this study were respectively $\mathrm{C}_{6} \mathrm{H}_{5} \mathrm{CH}_{2}+\mathrm{CH}_{3} \leftrightarrow \mathrm{C}_{6} \mathrm{H}_{5} \mathrm{C}_{2} \mathrm{H}_{5}$ and $\mathrm{C}_{6} \mathrm{H}_{5} \mathrm{C}_{2} \mathrm{H}_{5}+\mathrm{H}_{\leftrightarrow} \leftrightarrow \mathrm{C}_{6} \mathrm{H}_{5} \mathrm{C}_{2} \mathrm{H}_{3}+\mathrm{H}_{2}+\mathrm{H}$. O-Xylene $\left(\mathrm{CH}_{3} \mathrm{C}_{6} \mathrm{H}_{4} \mathrm{CH}_{3}\right)$ was well reproduced by the model through the reaction sequence of 1-methylallenyl self combination to form oXylyl $\left(\mathrm{CH}_{3} \mathrm{C}_{6} \mathrm{H}_{4} \mathrm{CH}_{2}\right)$ and $\mathrm{H}$-atom, followed by $\mathrm{o}-\mathrm{Xylyl}+\mathrm{H} \leftrightarrow \mathrm{O}-\mathrm{Xylene}$. The styrene measurements exhibited a peak concentration in the early stages in the main reaction zone and then decayed. The model was unable to reproduce this profile and instead exhibited a monotonic increase in styrene production. Styrene was produced exclusively by $\mathrm{C}_{6} \mathrm{H}_{5}+\mathrm{C}_{2} \mathrm{H}_{4} \leftrightarrow \mathrm{C}_{6} \mathrm{H}_{5} \mathrm{C}_{2} \mathrm{H}_{3}+\mathrm{H}$. Anthracene was underpredicted in the main reaction zone by a factor of ten but improved to within a factor of two further into the post-flame zone. The isomerization step, Phenanthrene $\leftrightarrow$ Anthracene as suggested by Colket and Seery [27], was used to model anthracene production. 9h-Fluorene was underpredicted by three orders of magnitude throughout the flame and therefore shows the reaction sequence, Phenanthryl-9+O $2 \leftrightarrow$ Phenanthroxy $-9+O$, Phenanthroxy $-9 \leftrightarrow$ Fluoryl $+\mathrm{CO}$ and Fluoryl $+\mathrm{H} \leftrightarrow 9 \mathrm{~h}$-Fluorene, does not produce the necessary $9 \mathrm{~h}$-Fluorene concentrations as measured in the flame.

\section{Benzo(ghi)fluoranthene, c-Penta(cd)pyrene, Fluoranthene, Methylnaphthalene and} 4h-c-Penta(def)phenanthrene The measured and predicted concentrations for these species are shown in figure 8. We were unsuccessful in modeling the Benzo(ghi)fluoranthene, c-Penta(cd)pyrene, and Fluoranthene concentrations as measured in the ethylene flame. The model underpredicted the concentrations of these three species by approximately factors of 100,30 , and 200 respectively. Further work is needed to understand the formation mechanisms of these polycyclic aromatics that have a shared $\mathrm{C}_{5}$ structure embedded in their fused rings. The methylnaphthalene was underpredicted by over one order of magnitude in the main reaction zone, however agreement to within a factor of 3 was achieved in the postflame zone. The reaction steps leading to methylnaphthalene formation were 
$\mathrm{C}_{10} \mathrm{H}_{7}+\mathrm{CH}_{3} \leftrightarrow \mathrm{C}_{10} \mathrm{H}_{7} \mathrm{CH}_{2}+\mathrm{H}$ followed by $\mathrm{C}_{10} \mathrm{H}_{7} \mathrm{CH}_{2}+\mathrm{H} \leftrightarrow \mathrm{C}_{10} \mathrm{H}_{7} \mathrm{CH}_{3}$. The 4 h-cPenta(def)phenanthrene concentration was well predicted from the main reaction zone to the post-flame zone. The reaction sequence producing $4 \mathrm{~h}-\mathrm{c}-\mathrm{Penta}(\mathrm{def})$ phenanthrene is Phenanthrene $+\mathrm{H} \leftrightarrow$ Phenanthryl $-1+\mathrm{H}_{2}$, Phenanthryl $+\mathrm{CH}_{3} \leftrightarrow 4 \mathrm{~h}-\mathrm{c}$-Penta(def)phenanthrene $+\mathrm{H}$.

Benzoapyrene, Perylene, Phenylnapthalene, Biphenylene and Biphenyl Modeling was not performed for these species (with the exception of biphenyl) and we have included this data as shown in Fig. 9 as part of the complete data set. We had modeled the biphenyl using the reaction steps, $\mathrm{C}_{6} \mathrm{H}_{5}+\mathrm{C}_{6} \mathrm{H}_{5} \leftrightarrow$ Biphenyl and $\mathrm{C}_{6} \mathrm{H}_{6}+\mathrm{C}_{6} \mathrm{H}_{5} \leftrightarrow$ Biphenyl $+\mathrm{H}$. The model underpredicted the biphenyl concentration by a factor of ten in the main reaction zone, however agreement to within a factor of three was achieved in the post-flame zone.

\section{Summary}

The modeling results show the key reaction sequences leading to aromatic and polycyclic aromatic hydrocarbon growth involve the combination of resonantly stabilized radicals. The combination reactions involving propargyl and 1-methylallenyl lead to benzene and methyl substituted benzene formation, while polycyclic aromatics are formed from cyclopentadienyl radicals and fused rings that have a shared $\mathrm{C}_{5}$ side structure. Naphthalene formation occurs from cyclopentadienyl self-combination and phenanthrene production takes place via indenyl and cyclopentadienyl combination. The removal of phenyl by $\mathrm{O}_{2}$ leading to cyclopentadienyl formation is expected to play a pivotal role in the PAH or soot precursor growth process under fuel-rich oxidation conditions.

\section{Acknowledgement}

We gratefully thank Wing Tsang and James Miller for the technical discussions concerning this research. The experimental work was supported by the Petroleum 
Environmental Research Forum Project 92-19. The modeling work was supported by the U.S. Department of Energy, Office of Industrial Technology and performed under the auspices of the U.S. Department of Energy by the Lawrence Livermore National Laboratory under contract No. W-7405-ENG-48. 


\section{References}

1. Harris, S.J., Weiner, A.M., and Blint, R.J., Combust. Flame, 72:91-109 (1988).

2. Dagaut, P., Boettner, J.C., and Cathonnet, M., Int. J. Chem. Kinet., 22: 641-664 (1990).

3. Levy, J.M., Taylor, B.R., Longwell, J.P., and Sarofim, A.F., Nineteenth Symposium (International) on Combustion, The Combustion Institute, Pittsburgh 1982, pp. 167-179.

4. Jachimowski, C.J.: Combust. Flame, 29: 55-66 (1977).

5. Bockhorn, H., Fetting, F., and Wenz, H., Ber. Bensenges. Phys. Chem., 87: 1067-1073 (1983).

6. Frenklach, M., and Warnatz, J., Comb. Sci. and Tech., 51:265-283 (1987).

7. Marinov, N.M., Pitz, W.J., Westbrook, C.K., Castaldi, M.J., and Senkan, S.M.: Comb. Sci. and Tech., Submitted.

8. Frenklach, M., Clary, D.W., Gardiner, W.C., Jr., and Stein, S.E., Twentieth Symposium (International) on Combustion, The Combustion Institute, Pittsburgh, 1985 , pp. 887-901.

9. Miller, J.A., and Melius, C.F., Combust. Flame, 91:21-39 (1992).

10. Fitch, W.L., and Sauter, A.D., Anal. Chem., 55:832-835 (1983).

11. Kee, R.J., Grcar, J.F., Smooke, M.D., and Miller, J.A., A Fortran Program for Modeling Steady Laminar One-Dimensional Premixed Flames, Sandia Report \#SAND85-8240 (1985).

12. Kee, R.J., Rupley, F.M., and Miller, J.A., The Chemkin Thermodynamic Data Base, Sandia Report \#SAND87-8215B (1987).

13. Burcat, A., and McBride, B., 1994 Ideal Gas Thermodynamic Data for Combustion and Air-Pollution Use, Techion Report \#TAE 697 (1993).

14. Stein, S.E., and Fahr, A., J. Phys. Chem., 89:3714-3725 (1985).

15. Stein, S.E., and Brown, R.L., J. Am. Chem. Soc., 113:787-793 (1991).

16. Benson, S.W., (1976), Thermochemical Kinetics, Second Edition, John Wiley and Sons.

17. Kee, R.J., Dixon-Lewis, G., Warnatz, J., Coltrin, M.E., and Miller, J.A., The Chemkin Transport Database, Sandia Report \#SAND86-8246 (1986).

18. Wang, H., and Frenklach, M., Combust. Flame, 96:163-170 (1994).

19. Tsang, W., J. Phys. Chem. Ref. Data, 17(2): 887-951 (1988). 
20. Tsang, W., J. Phys. Chem. Ref. Data, 20(2): 221-273 (1991).

21. Pitz, W.J., Westbrook, C.K., and Leppard, W.K., SAE Transactions, SAE Paper No. 912315 (1991).

22. Emdee, J., Brezinsky, K., and Glassman, I., J. Phys. Chem., 96:2151-2161 (1992).

23. Wang, H., and Frenklach, M., J. Phys. Chem., 98:11465-11489 (1994).

24. Frank, P., Herzler, J., Just, Th., and Wahl, C.: Twenty-Fifth Symposium (International) on Combustion, The Combustion Institute, Pittsburgh, 1994, pp. 833-840.

25. Glassman, I.: Combustion, Second Edition, Academic Press, New York, 1986.

26. Melius, C.F., Colvin, M.E., Marinov, N.M., Pitz, W.J., and Senkan, S.M.: Twenty-Sixth Symposium (International) on Combustion, The Combustion Institute, Pittsburgh, 1996, Submitted.

27. Colket, M.B., and Seery, D.J., Twenty-Fifth Symposium (International) on Combustion, The Combustion Institute, Pittsburgh, 1994, pp. 883-891. 
Figure Captions

Figure 1. Comparison of model predictions with experimental concentration profiles. Symbols represent the experimental measurements and the curves represent the model predictions for $\mathrm{C}_{2} \mathrm{H}_{4}, \mathrm{O}_{2}, \mathrm{H}_{2}$ and $\mathrm{H}_{2} \mathrm{O}$.

Figure 2. Comparison of model predictions with experimental concentration profiles. Symbols represent the experimental measurements and the curves represent the model predictions for $\mathrm{CO}, \mathrm{CO}_{2}, \mathrm{CH}_{4}$, and $\mathrm{C}_{2} \mathrm{H}_{2}$.

Figure 3. Comparison of model predictions with experimental concentration profiles. Symbols represent the experimental measurements and the curves represent the model predictions for $\mathrm{C}_{2} \mathrm{H}_{6}, \mathrm{C}_{3} \mathrm{H}_{4}, \mathrm{C}_{4} \mathrm{H}_{2}$, and $\mathrm{C}_{4} \mathrm{H}_{4}$.

Figure 4. Comparison of model predictions with experimental concentration profiles. Symbols represent the experimental measurements and the curves represent the model predictions for $\mathrm{C}_{4} \mathrm{H}_{6}, \mathrm{C}_{4} \mathrm{H}_{8}$, and $\mathrm{c}-\mathrm{C}_{5} \mathrm{H}_{6}$. Radiation corrected temperature profile shown.

Figure 5. Comparison of model predictions with experimental concentration profiles. Symbols represent the experimental measurements and the curves represent the model predictions for Benzene, Toluene, Naphthalene, and Phenyl Acetylene. 
Figure 6. Comparison of model predictions with experimental concentration profiles. Symbols represent the experimental measurements and the curves represent the model predictions for Indene, Phenanthrene, Acenaphthylene, and Pyrene.

Figure 7. Comparison of model predictions with experimental concentration profiles. Symbols represent the experimental measurements and the curves represent the model predictions for Ethyl Benzene, o-Xylene, Styrene, Anthracene and $9 \mathrm{~h}$-Fluorene (model prediction not shown, see text).

Note: Logarithmic scale used.

Figure 8. Comparison of model predictions with experimental concentration profiles. Symbols represent the experimental measurements and the curves represent the model predictions for Benzo(ghi)fluoranthene, c-Penta(cd)pyrene, Fluoranthene (model prediction not shown, see text), Methylnaphthalene, and $4 \mathrm{~h}$-c-Penta(def)phenanthrene. Note: Logarithmic scale used.

Figure 9. Symbols represent experimental measurements to Benzoapyrene, Perylene, Phentlnaphthalene, Biphenylene, and Biphenyl. Model prediction shown for Biphenyl by drawn curve. Note: Logarithmic scale used. 


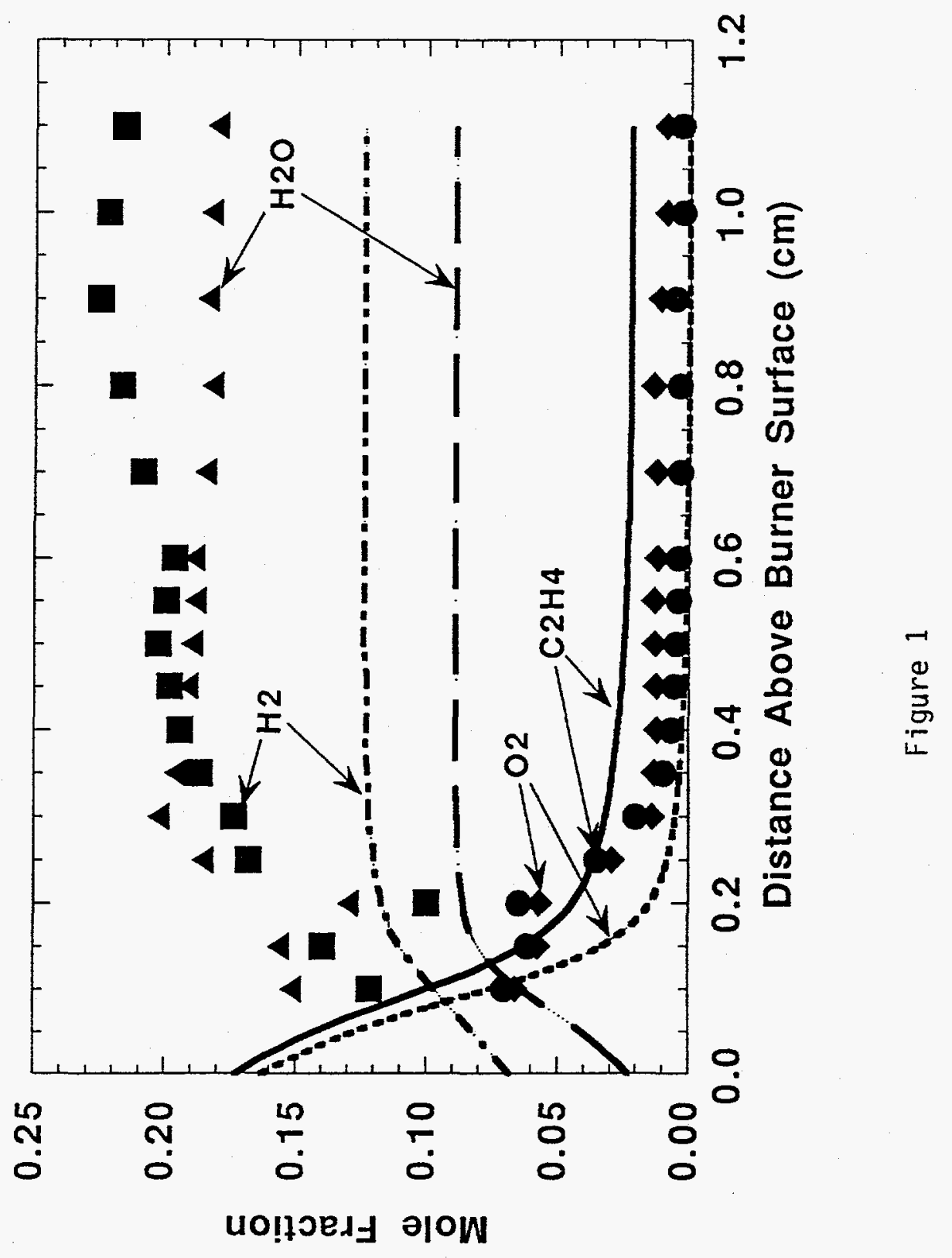




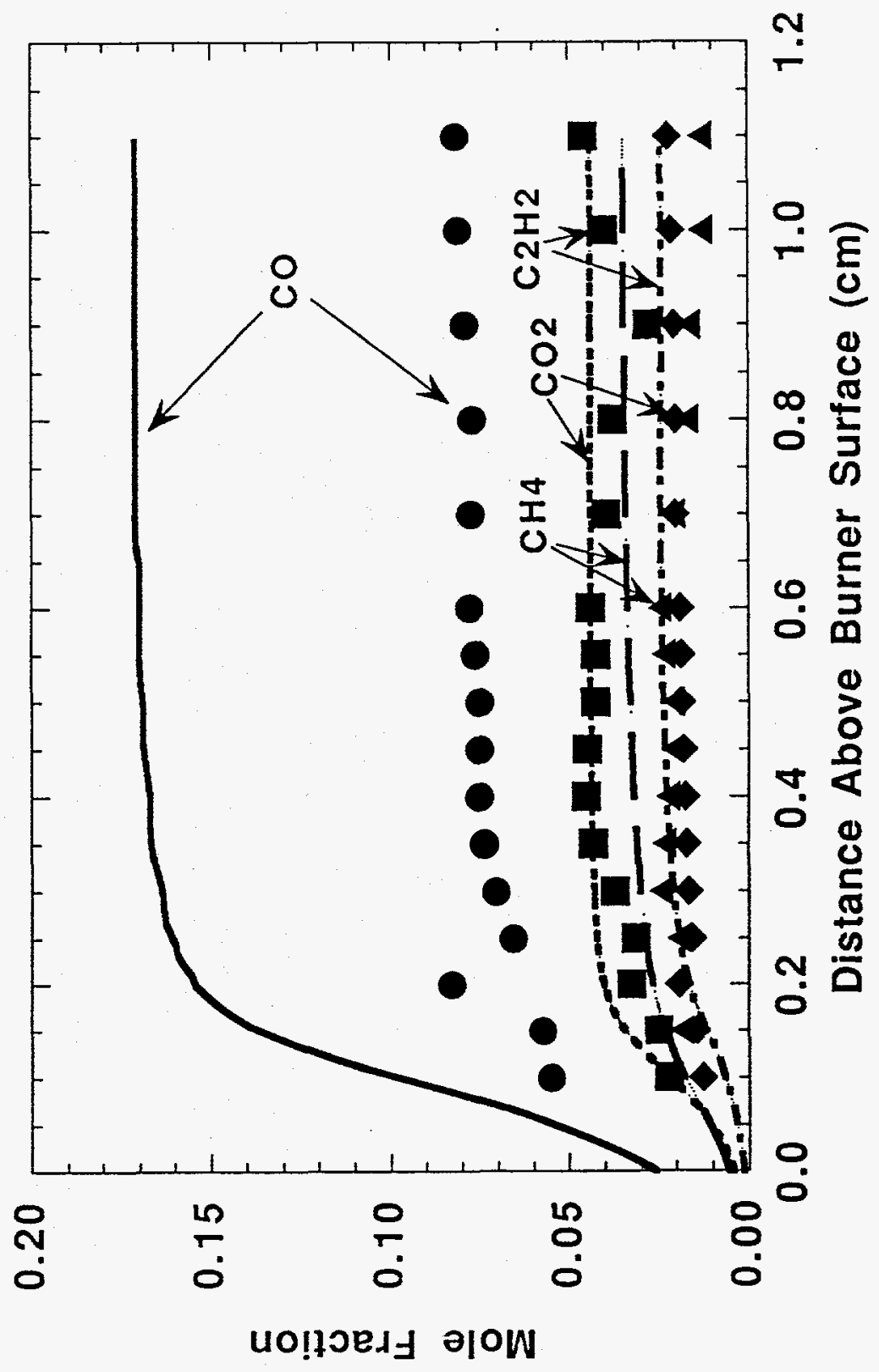

$N$
$\frac{0}{3}$
吕 


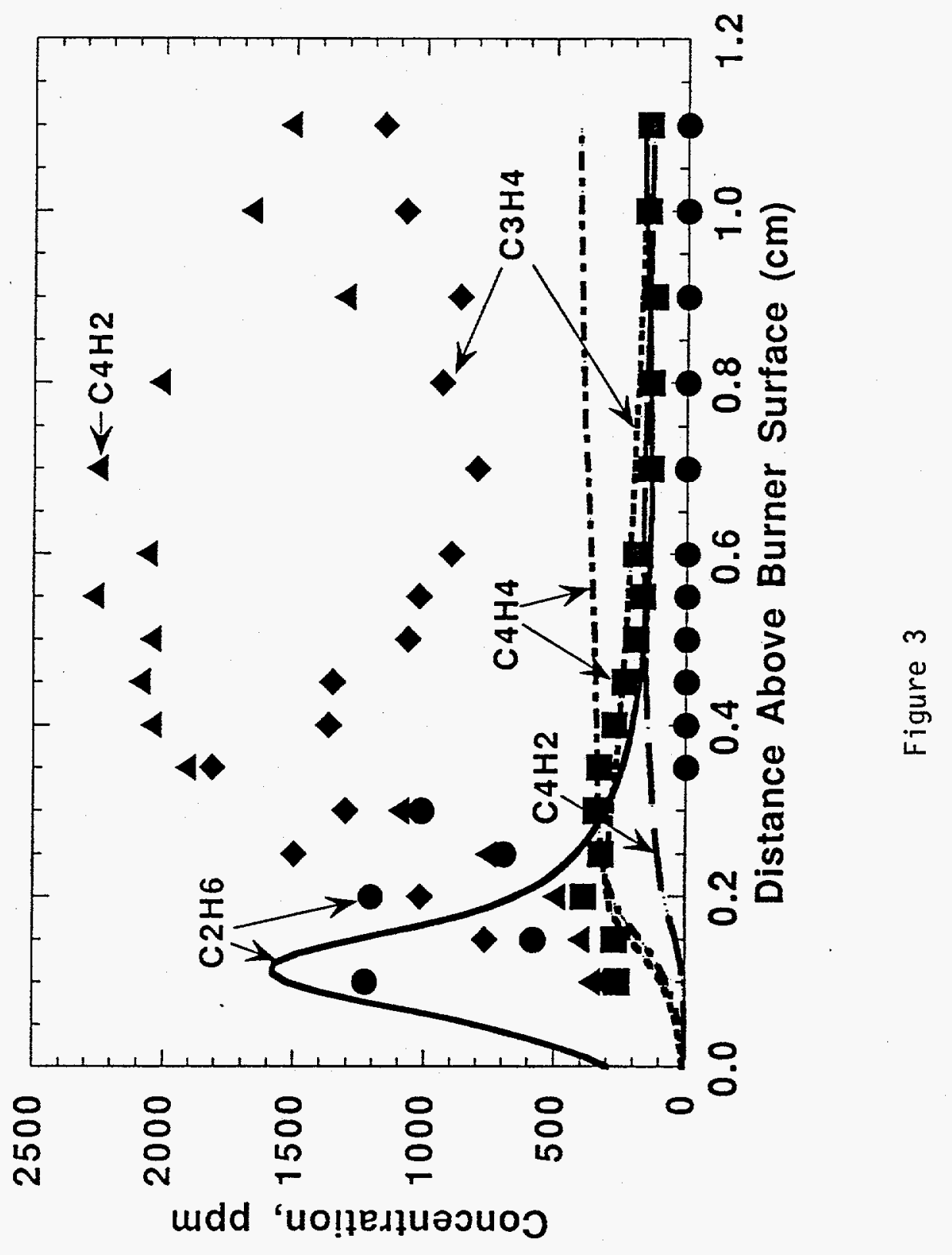




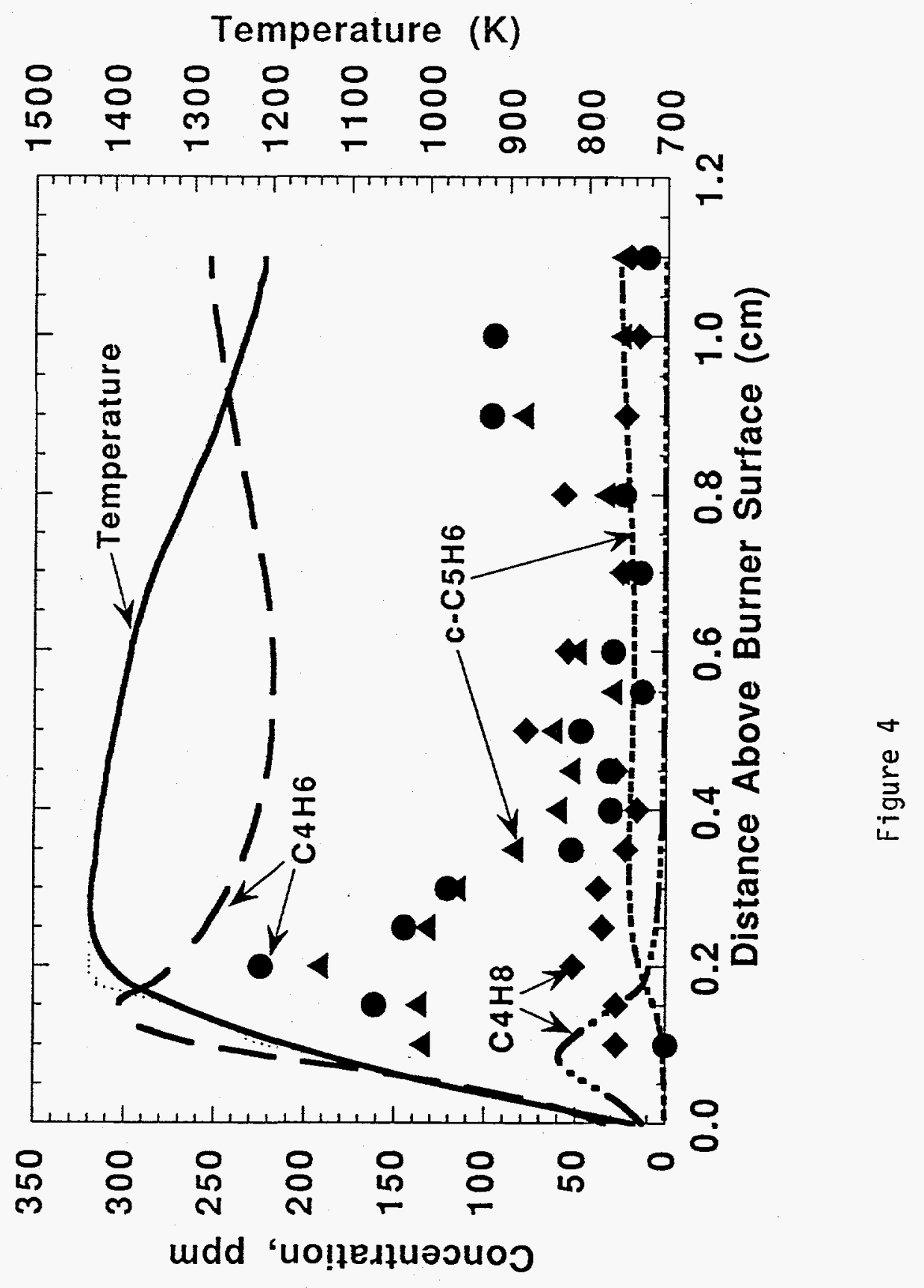




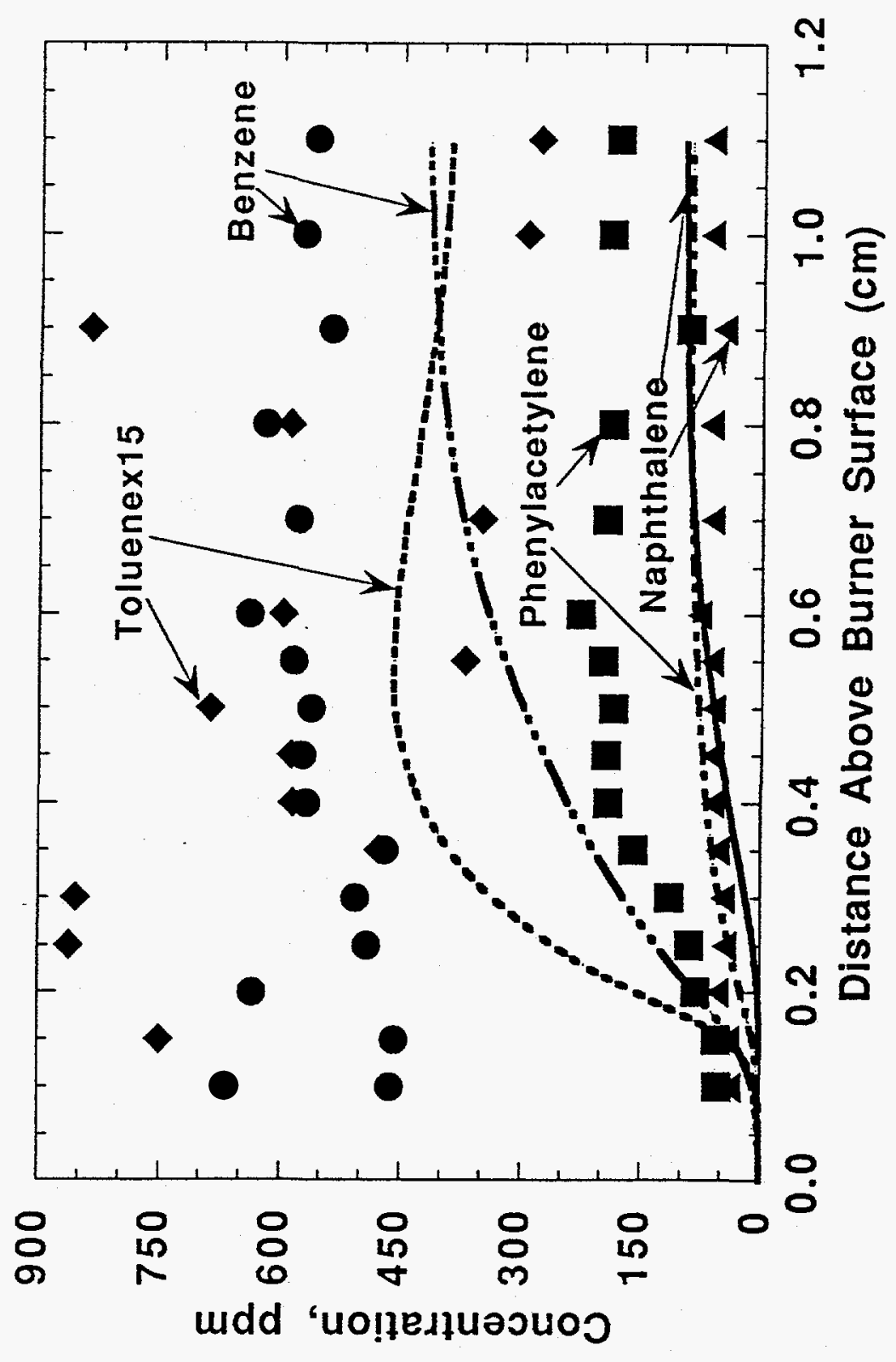

吕 


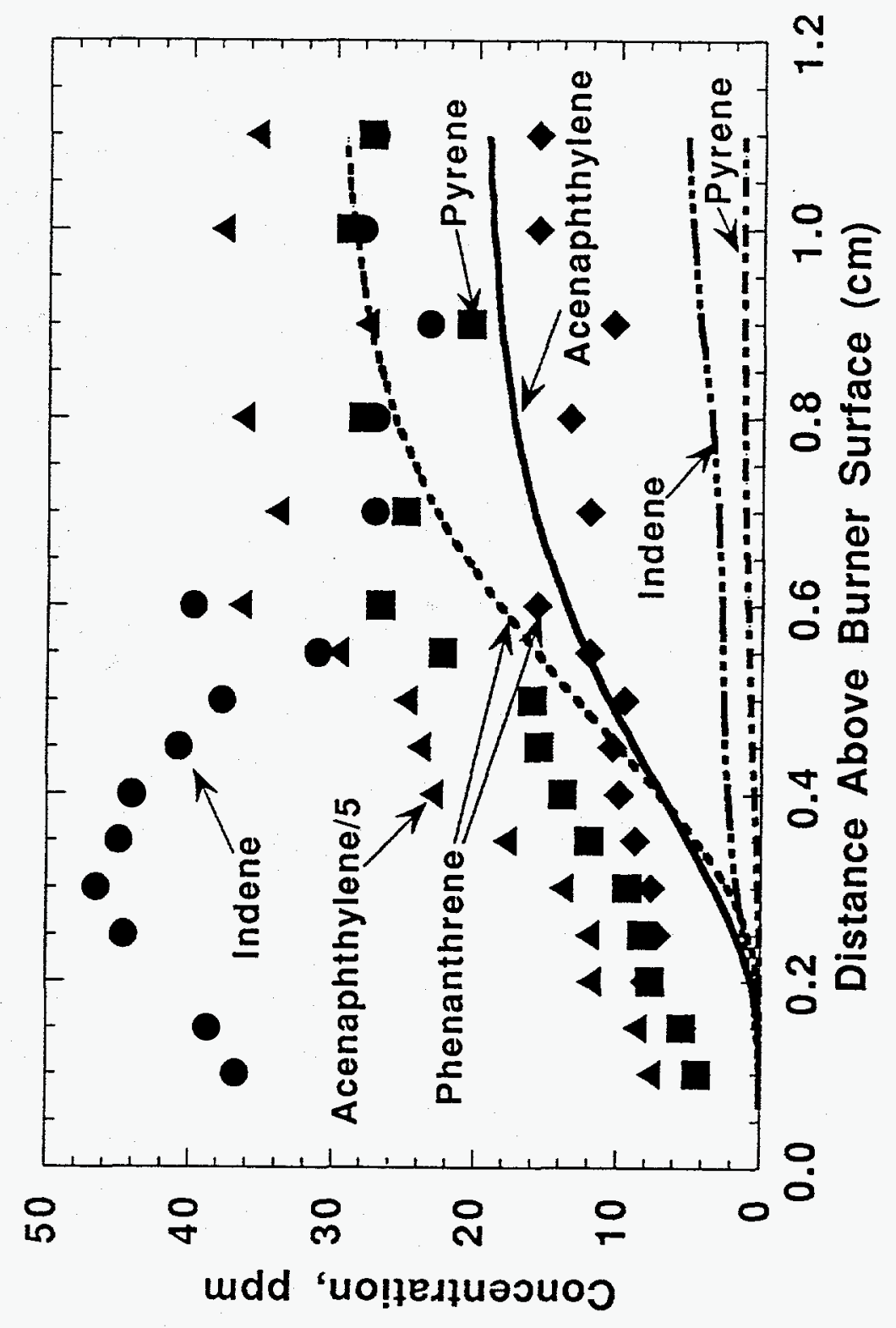

0
4
$\frac{1}{3}$
$\frac{5}{4}$ 


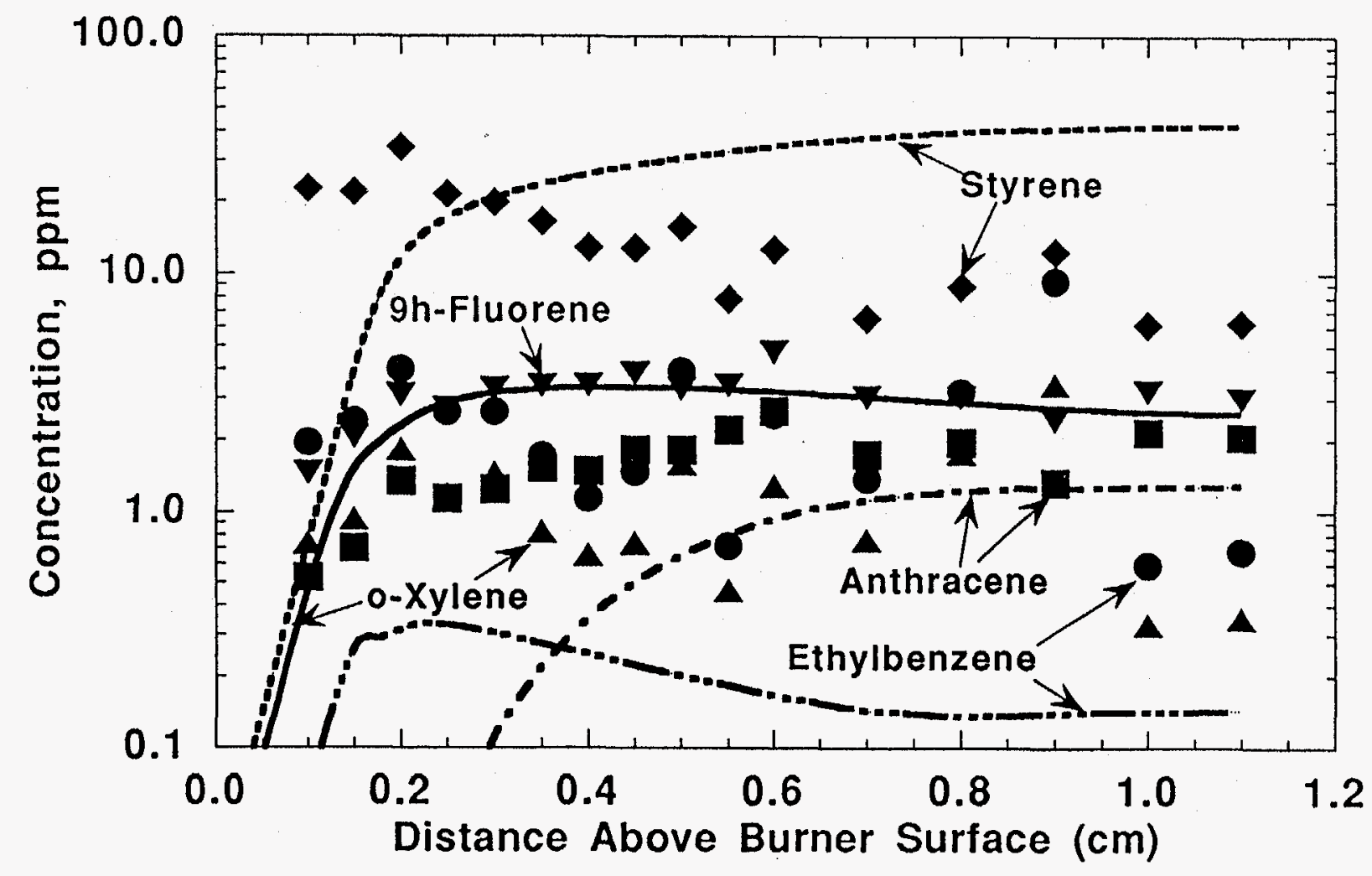

Figure 7 


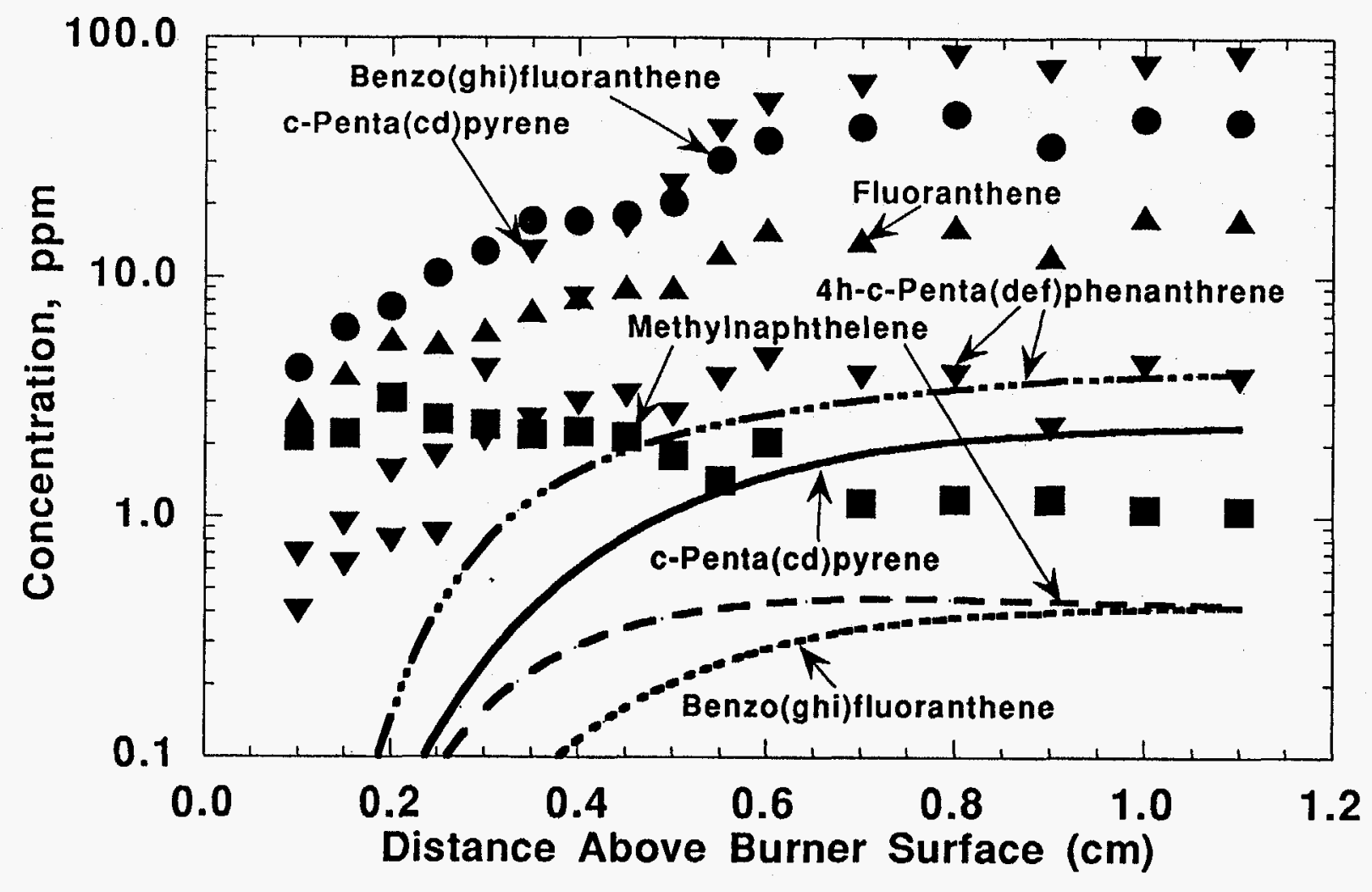

Figure 8 


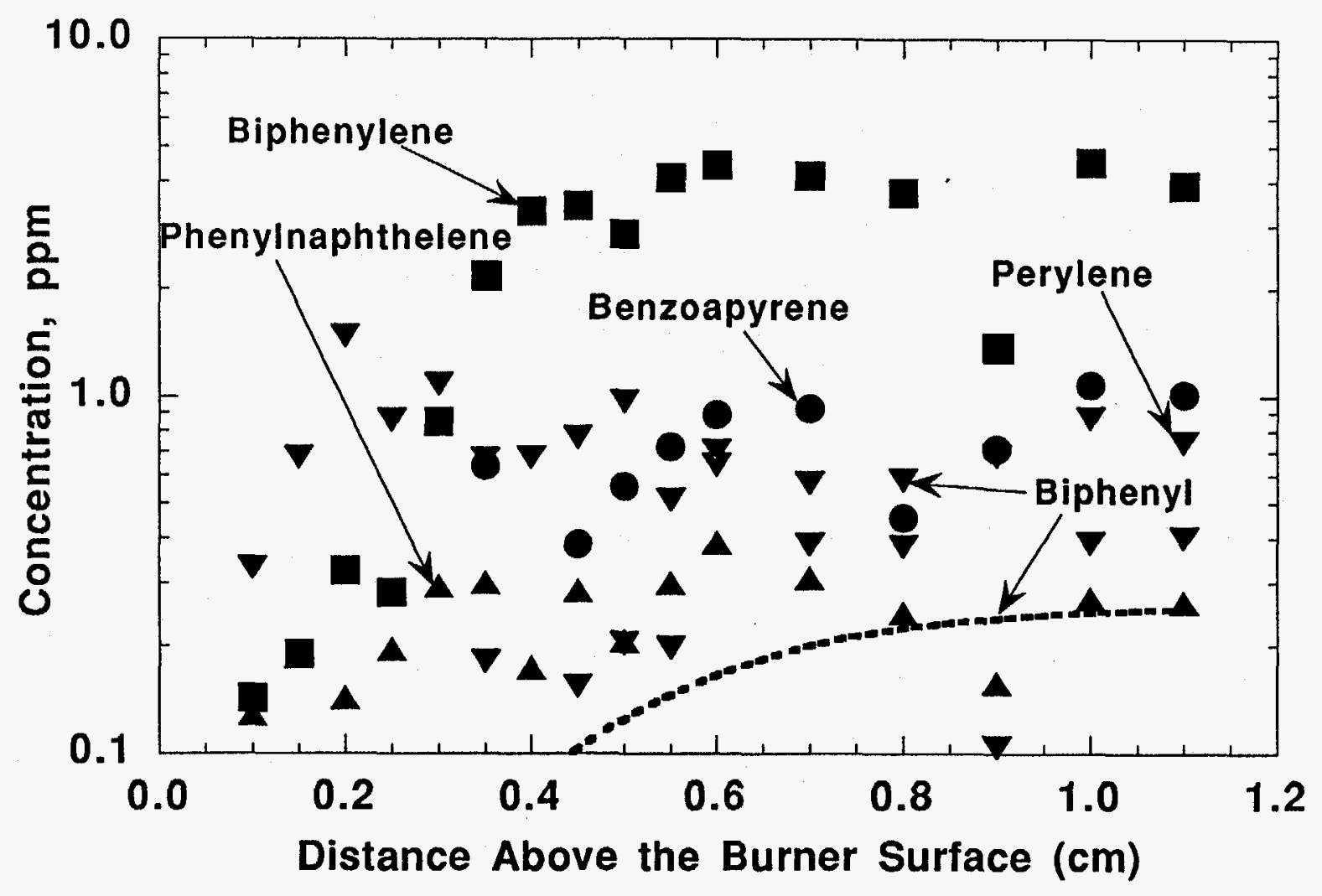

Figure 9 